\title{
Analisis Media Edukasi Puzzle Untuk Pendidikan Karakter Anak Usia Dini
}

\author{
Lisa Mardiana ${ }^{a^{*}}$, Mutia Rahmi Pratiwi $^{\mathrm{b}}$, Dzuha Hening Yanuarsaric \\ aUniversitas Dian Nuswantoro \\ *lisa.mardiana@dsn.dinus.ac.id
}

\begin{abstract}
Early childhood character education is a crucial phase that requires serious attention. Media education is a solution in delivering messages related to early childhood character education. The purpose of this research is to analyze the puzzle media that has existed before so that it can be the basis for developing the puzzle media that will be designed by the author based on the development of children's self-concepts as part of character education. This research is a qualitative research with case study method. The resource persons who became the research subjects were two practitioners, namely child psychologists and practitioners of children's education media. The results show that puzzle educational media can be a solution for delivering character education to children and it is necessary to design educational media in the form of puzzles based on character education and the role of parents with the aim of developing self-esteem and selfconfidence in it.
\end{abstract}

Keywords: Parenting Communication, Educational Media, Interpersonal Communication

\section{Latar Belakang}

Anak merupakan bagian dari keluarga yang menjadi tanggung jawab orang tua. Pendidikan anak usia dini merupakan salah satu tugas besar orang tua pada awal perkembangan anak sejak lahir hingga usia enam tahun, di mana pada fase ini anak dipersiapkan untuk menempuh pendidikan pada tahap selanjutnya. Menurut (Zahro, 2015), pendidikan pada anak usia dini merupakan pendidikan paling dasar dan paling penting karena adanya komitmen internasional untuk Education for All (EFA). Berbagai kajian ilmiah menunjukan urgensi pendidikan ini karena anak berada pada fase golden age dan dasar Undang-Undang yang menjadi acuan yaitu UU No.20 tahun 2003.

Pada anak usia dini terdapat enam aspek perkembangan yang utama, yaitu: (1) aspek perkembangan nilai dan agama; (2) aspek perkembangan fisik dan motoric; (3) aspek perkembangan bahasa; (4) aspek sosial emosional; (5) aspek perkembangan kognitif; dan (6) aspek perkembangan seni (Dewi \& Handayani, 2019). Dalam perkembangan otak manusia, tahap perkembangan otak pada anak usia dini menempati posisi yang paling vital, yakni mencapai $80 \%$ perkembangan otak sehingga menjadi cerminan diri untuk melihat keberhasilan anak dimasa mendatang (Admin, 2016). Ketika seorang anak berhasil untuk melewati pendidikan usia dini dengan baik, maka dampaknya akan dapat dirasakan oleh anak secara jangka panjang, di antaranya berdampak pada kesehatan mental dan fisiknya; prestasi belajar yang terus meningkat; memiliki etos kerja yang baik sehingga produktivitas, kemandirian, serta potensi diri yang dimiliki anak akan terus berkembang secara optimal (El-Khuluqo, 2015).

Pendidikan anak usia dini dari sisi pembangunan karakter positif anak memerlukan perhatian yang serius. Meskipun banyak teori, program dan nilai-nilai yang ada mengenai pentingnya pendidikan anak usia dini dan kasus mengenai pendidikan karakter di Indonesia masih banyak terjadi. Disebutkan bahwa KPAI telah banyak menangani kasus hingga 1885 pada semester pertama tahun 2018. Sebanyak 504 anak 
menjadi pelaku pidana mulai dari kasus narkoba, mencuri, hingga tindak asusila menjadi kasus yang paling banyak terjadi (Ikhsanudin, 2018). Pada kasus anak berhadapan dengan hukum $(\mathrm{ABH})$, banyak anak yang masuk Lembaga Pemasyarakatan Khusus Anak (LPKA) karena mencuri sebanyak 23,9\%, terlibat kasus narkoba sebanyak 17,8\%, dan kasus asusila sebanyak 13,2\%. Melansir dari data Komisi Perlindungan Anak, tercatat $62,7 \%$ anak usia remaja pada jenjang sekolah menengah pertama (SMP) di Indonesia sudah tidak lagi perawan. Hasil lainnya mencatat 93,7\% peserta didik jenjang SMP dan jenjang sekolah menengah atas (SMA) sudah pernah melakukan adegan berciuman, 21,2\% remaja usia SMP mengaku pernah melakukan tindak aborsi, dan 97\% remaja SMP dan SMA pernah melihat film porno (Suhendi, 2010).

Menurut data dari Rizky Rahayu Setyawan, tenaga pembimbing kemasyarakatan pada Balai Pemasyarakatan (Bapas) Cilacap, selama masa pandemi Covid-19 kasus ABH di Jawa Tengah mengalami peningkatan sebanyak 10\%. Berdasar data dari Lembaga Perlindungan Anak (LPA), hingga akhir tahun 2020 tercatat 80 anak memiliki kasus hukum. Kejenuhan di rumah dan keluhan orang tua karena anak sulit membiasakan diri untuk di rumah karena masa pandemi dan sekolah daring menjadi salah satu faktor kasus ABH pada anak (Farasonalia, 2021).

Berbagai kasus penyimpangan karakter anak di berbagai usia mungkin saja merupakan dampak tidak tuntasnya pendidikan usia dini yang dilaluinya serta dampak buruk atas lingkungan di kalangan peer group. Maka sangat penting untuk mengambil langkah strategis sebagai upaya penguatan nilai karakter anak melalui media yang implikatif, di mana di dalamnya mengandung unsur percontohan dari orang tua sebagai guru pertama anak.

Dalam proses pendidikan karakter pada anak usia dini diperlukan repetisi. Hal ini karena proses membangun karakter tidaklah instan dan berdampak secara jangka panjang. Dalam prosesnya memerlukan suasana belajar yang kondusif pada anak sehingga nilai karakter dapat dipahami secara lebih optimal (Khoiri, 2018). Pendidikan yang dibutuhkan anak tidak lepas dari kebutuhan kasih sayang, pengoptimalan panca indra yang dimiliki, penguatan konsep diri, mengeksplorasi lingkungan sekitar, serta proses interaksi atau proses berkomunikasi dengan lingkungan sekitar. Dalam proses perkembangan diri anak, diperlukan kontribusi orang tua sebagai pemeran utama saat proses belajar anak sehingga dapat memperoleh hasil yang optimal (Rahmasari dan Yanuarsari, 2017).

Penanaman beragam nilai karakter pada anak diperlukan untuk mengembangkan potensi dan memperkuat nilai karakter positif pada diri setiap anak. Salah satu uji penanaman nilai karakter pada anak dilakukan melalui permainan edukatif di ruang terbuka. Beberapa permainan yang telah diujikan pada anak adalah puzzle, bola emas, hujan salju, estafet karet, dan hydro tower. Hasil uji menunjukan bahwa dengan melakukan berbagai permainan edukatif dengan teman sebaya, anak belajar tentang karakter kedisiplinan, kerjasama, kerja keras, mandiri, menghargai, serta peduli lingkungan dan sosial (Dewi \& Handayani, 2019). Pembentukan perilaku anak dimulai sejak anak berusia dini dan ini menjadi dasar anak dalam memahami konsep norma yang berlaku di masyarakat tempat ia tinggal. Pemahaman anak mengenai norma akan berdampak pada perilaku anak, mulai dari bagaimana bersikap hingga berbicara dengan baik dan sopan (Pratiwi, dkk, 2019).

Perkembangan teknologi telah melahirkan media edukasi yang kreatif dan inovatif dalam bentuk permainan, seperti puzzle, buku cerita, dan game edukasi. Permainan dinilai menjadi media yang efektif untuk menyampaikan pesan moral berbasis karakter pada anak karena dunia anak adalah dunia bermain, sehingga 
kemungkinan pesan utama terserap lebih tinggi. Hal ini selaras dengan apa yang disampaikan oleh Moeslichatoen (Hasanah, 2016). Ia menyatakan bahwa pada saat anak bermain, ia akan menyerap berbagai hal yang terjadi di lingkungannya karena bermain pada anak merupakan kebutuhan esensial yang dapat memuaskan kebutuhan anak, mulai dari motorik hingga sikap hidup.

Media edukasi menjadi media yang dinilai efektif untuk menanamkan nilai pada anak. Media ini melibatkan orang tua, baik dalam proses penyampaian pesan maupun dalam konten media itu sendiri. Menurut Hadi (2016), sebagai bagian utama dari pembentukan keluarga, orang tua memiliki kewajiban dan bertanggung jawab atas pengasuhan, pendidikan, hingga perlindungan pada anak. Orang tua merupakan pintu pendidikan pertama dalam pembentukan kepribadian anak, di mana sikap yang ditunjukan orang tua dalam keseharian akan menjadi tolok ukur anak dalam meniru. Proses interaksi antara orang tua dan anak merupakan sistem komunikasi yang kompleks, serta lingkungan perkembangan utama bagi anak dalam masa pertumbuhan karakter dalam dirinya. Hal ini dikarenakan sejak awal kehadirannya, orang tua menjadi orang pertama yang ia contoh, atau seringkali disebut bahwa anak adalah cerminan orang tuanya (Marilena, 2015).

Hasil observasi peneliti menunjukan beberapa peneliti telah melakukan penelitian mengenai media edukasi yang berkaitan dengan pendidikan karakter pada anak. Namun, masih belum ada kajian terkait media edukasi yang nilai utamanya adalah nilai karakter dan peranan orang tua pada pendidikan anak. Berdasarkan hasil observasi peneliti, terdapat lima rancangan media edukasi puzzle yang telah dilakukan peneliti sebelumnya, mulai dari yang berkonsep konvensional hingga berbasis teknologi. Kelima media edukasi tersebut yang menjadi objek penelitian ini, yaitu Media Edukasi Puzzle Animasi Interaktif, Lego (puzzle dan bingo), Game Puzzle Wayang Punakawan, Edufunzle dan Puzzle 7 Hewan Langka.

Penelitian ini bertujuan untuk menganalisa media edukasi puzzle yang telah ada sebelumnya, sehingga dapat menjadi dasar pengembangan media puzzle yang akan dirancang peneliti. Penelitian ini menggunakan tiga dasar tinjauan teoritis, yaitu media edukasi, perkembangan kognitif anak, dan peranan orang tua. Media merupakan segala sesuatu yang digunakan untuk menyampaikan berbagai pesan dengan tujuan merangsang pikiran, perasaan, perhatian, hingga minat anak usia dini, sehingga proses belajar pada anak dapat berlangsung dengan baik (Khadijah, 2015). Media pembelajaran untuk anak usia dini merupakan media yang memiliki nilai edukasi yang ditujukan untuk meningkatkan kemampuan anak serta dapat digunakan secara individual maupun kelompok (Dewi \& Handayani, 2019).

Istilah lain dari media edukasi adalah alat peraga edukasi (APE). APE bertujuan untuk merangsang kreativitas anak yang bertujuan untuk meningkatkan kemampuan anak di sisi pengetahuan tertentu dengan pendekatan permainan. Dalam proses penyerapan pengetahuan, anak akan melaluinya secara tidak langsung melalui media edukasi. Alat peraga edukasi dapat dirancang berdasar pada kajian teori tertentu yang berkaitan dengan aspek perkembangan anak sesuai kategori usianya. Beberapa tujuan dalam pembuatan alat peraga edukasi di antaranya meningkatkan stimulus anak, peningkatan kosakata dalam berbahasa, dan peningkatan pengetahuan (Rofiah, 2021).

Yang kedua adalah teori Piaget tentang perkembangan kognitif anak. Teori ini menyatakan bahwa anak pada rentang usia di bawah lima tahun memiliki berbagai kemampuan dalam menghadapi beragam objek di sekitarnya dan kemampuan utama anak adalah kemampuan sensor motorik. Ketika seorang anak memperoleh banyak informasi dari orang dewasa di sekitarnya, maka hal ini akan membawa perkembangan 
pada setiap anak secara beragam. Piaget membagi perkembangan kognitif menjadi empat tahapan berdasar rentang usia dan kemampuan yang dimiliki anak secara general, yaitu: (1) tahap sensori motorik yang dilalui sejak anak berusia 0-2 tahun; (2) tahap pra operasional yang dilalui sejak anak berusia 2-7 tahun; (3) tahap operasional kongkrit yang dilalui sejak anak berusia 7-11 tahun; dan (4) tahap operasional formal yang dilalui sejak anak berusia 11-15 tahun. Pada tahapan pra-operasional, anak-anak berada pada fase cara pemikiran yang lebih simbolis, di mana anak lebih bersifat egosentris dan intuitis. Pada tahap ini, anak mengalami perkembangan bahasa dan kemunculan sikap dalam bermain. Egosentrisme merupakan ketidakmampuan anak dalam membedakan perspektif diri dengan perspektif orang lain (Mu'min, 2013).

Teori selanjutnya berkaitan dengan peranan orang tua yang diawali dengan regulasi program parenting. Program parenting atau program keayahbundaan merupakan salah satu program pemerintah yang bertujuan untuk memperkuat kehidupan di masyarakat terutama pada perkembangan anak usia dini. Landasan hukum program keayahbundaan adalah UU Nomor 15 Tahun 2015 yang merupakan perubahan atas UU Nomor 20 tahun 2013 tentang Perlindungan Hak Anak. Tujuan dari program ini adalah untuk melindungi hak anak atas berbagai tindakan yang sifatnya verbal maupun nonverbal yang menghambat tumbuh kembang anak sejak anak usia dini. Idealnya, anak-anak dapat mendefinikan identitas pribadi serta karakter dirinya sejak dini, sehingga anak memahami konteks kepribadian yang dewasa, bijaksana dan bertanggungjawab. Terdapat tiga peran utama ayah ibu dalam upaya pengembangan karakter anak, yaitu: (1) orang tua berkewajiban menciptakan suasana yang hangat dan tentram. Tidak tercapainya ketentraman di dalam keluarga akan menimbulkan terhambatnya pertumbuhan jiwa anak; (2) orang tua menjadi panutan bagi anak sehingga anak belajar secara langsung dari apa yang dialaminya setiap hari bersama orang tua (anak melihat, anak mendengar). Karakter orang tua akan menjadi perilaku nyata yang menjadi bahan ajar utama anak yang dengan mudah diserap oleh anak-anak. (3) Orangtua bekewajiban mendidik anak dengan karakter yang baik sehingga anak dibina dan berkembang sesuai fitrahnya. Hal ini karena perkembangan anak berjalan secara gradual dan tidak dapat diulang (Akhyadi \& Mulyono, 2019).

Orangtua merupakan lingkungan sosial pertama anak sekaligus yang utama karena menjadi fondasi keluarga yang di dalamnya terjadi proses pengasuhan dengan tujuan pembentukan karakter anak. Peran orang tua adalah sebagai pengendali sekaligus pemimpin dalam menanamkan nilai-nilai yang baik pada anak sesuai norma yang berlaku di masyarakat (Retno Dwiyanti., 2013).

\section{Metode Penelitian}

Penelitian ini merupakan jenis penelitian kualitatif dengan metode studi kasus. Studi kasus merupakan metode yang dapat digunakan dengan tujuan untuk mengidentifikasi masalah penelitian, di mana di dalamnya tidak memisahkan antara konteks dengan fenomena yang terjadi. Studi kasus berfokus pada kasus tertentu yang sifatnya mendalam, khas, dan unik (Prihatsanti, dkk, 2018).

Dalam implementasi metode studi kasus, peneliti memiliki kekuatan untuk mengungkap makna yang tersirat maupun yang tersurat sehingga temuan penelitian yang diperoleh bersifat mendalam. Teknik pengumpulan data penelitian pada metode studi kasus adalah wawancara, dokumentasi, dan observasi, baik secara langsung maupun peneliti terlibat langsung; serta pengumpulan data dalam bentuk fisik (Rahardjo, 2017).

Menurut Stake, terdapat empat bentuk analisis data pada penelitian yang 
menggunakan metode studi kasus, yaitu: (1) pengumpulan kategori data sehingga muncul ragam data yang berkaitan dengan isu yang dibahas; (2) interpretasi langsung yang dilakukan oleh peneliti dengan melihat ragam data yang diperoleh; (3) peneliti membentuk pola atas data maupun objek penelitian yang telah ditentukan sehingga terlihat keterakaitan satu dan lainnya; (4) peneliti melakukan generalisasi naturalistik dengan analisa data dari objek penelitian serta subjek yang relevan sehingga muncul simpulan atas suatu kasus maupun populasi kasus. Dapat disimpulkan bahwa tipe analisis data dari studi kasus sifatnya holistik atau menyeluruh sehingga nampak bahwa kasus yang muncul adalah kasus yang spesifik dan unik (Kusmarni, 2012).

Pada penelitian ini, teknik analisis data yang dilakukan adalah dengan memetakan media edukasi yang ditujukan untuk anak usia dini dan mewawancara pihak kompeten untuk menjadi dasar pengembangan media edukasi selanjutnya. Kemudian, peneliti mencari keterkaitan antara objek penelitian, yaitu media edukasi puzzle yang telah ada sebelumya, hasil wawancara, dan dengan teori yang relevan sehingga diperoleh hasil akhir berupa generalisasi temuan penelitian atas analisis yang dilakukan secara tekstual maupun narasi wawancara.

Subjek penelitian ini terdiri dari dua orang yaitu, Watiek Ideo sebagai praktisi media anak, penulis buku anak, dan pencipta media edukasi, dan Maria Wening S. Handayani, seorang psikolog anak. Sumber data primer diperoleh dari hasil wawancara dengan narasumber dan didukung dengan data observasi penelitian sebelumnya dari jurnal yang relevan, serta tinjauan pustaka dari beragam sumber. Peneliti mengambil sudut pandang dari pihak yang kredibel untuk memperkuat analisa data tekstual yang sudah diperoleh sebelumnya sehingga memperkuat perancangan media edukasi berbasis pendidikan karakter anak dengan fokus pada self esteem dan self confidence anak.

\section{Hasil dan Pembahasan}

\section{Analisa Temuan Penelitian terkait Media Edukasi Puzzle}

Hasil penelitian yang dilakukan melalui literature review menunjukan bahwa terdapat beberapa perancangan media edukasi puzzle yang telah dibuat oleh peneliti sebelumnya dengan cukup beragam. Pada tahun 2014 misalnya, Wardhani dan Wajiyono merancang puzzle animasi interaktif yang tujuannya adalah melatih kemampuan spasial anak. Anak yang memiliki kecerdasan spasial memiliki beberapa ciri, di antaranya suka menggambar, bermain warna, dan gemar bermain bongkar pasang. Konsep utama dari animasi interaktif puzzle ini adalah memperkenalkan tokoh kartun anak, tokoh superhero dan binatang dengan tingkat kesulitan mudah (easy), sedang (medium), dan sulit (hard) (Wardhani \& Warjiyono, 2014).
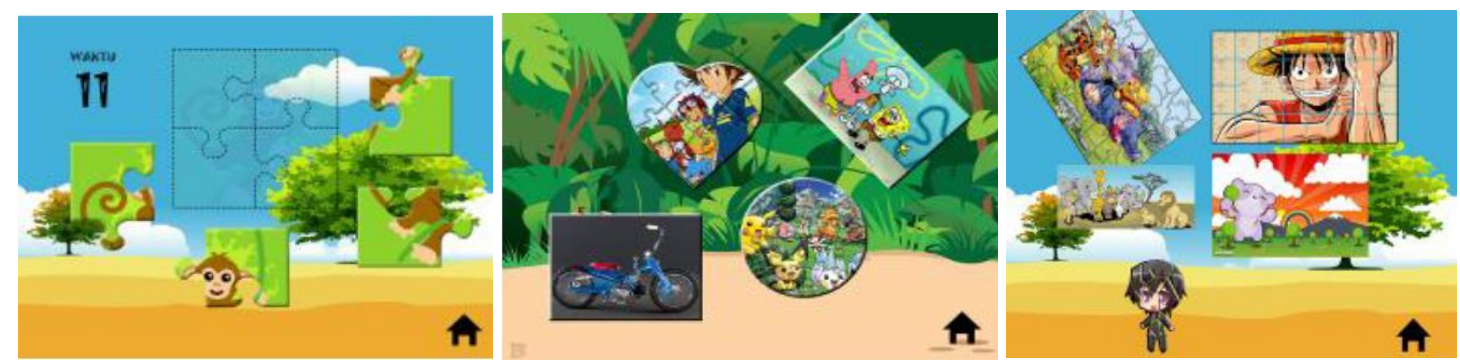

Gambar 1.1. Media Edukasi Puzzle Animasi Interaktif

Perancanan media edukasi puzzle lainnya berbasis pada konsep pengembangan nilai karakter diri pada anak. Abdullah dan Hastuti pada tahun 2015 merancang Lego (puzzle bingo) yang merupakan perpaduan puzzle (identik dengan bongkar pasang 
potongan gambar) dan bingo (menyusun item tertetu pada papan secara horizontal/ vertikal). Lego (puzzle bingo) memiliki satu papan permainan yang terdiri dari 18 kotak, di mana 18 kotak tersebut berisi nilai pendidikan karakter pada anak. Konsep permainan ini adalah berkelompok karena terdapat papan bermain dan dadu untuk memilih konsep nilai karakter yang akan dipelajari melalui permainan (Abdullah, dkk, 2016).

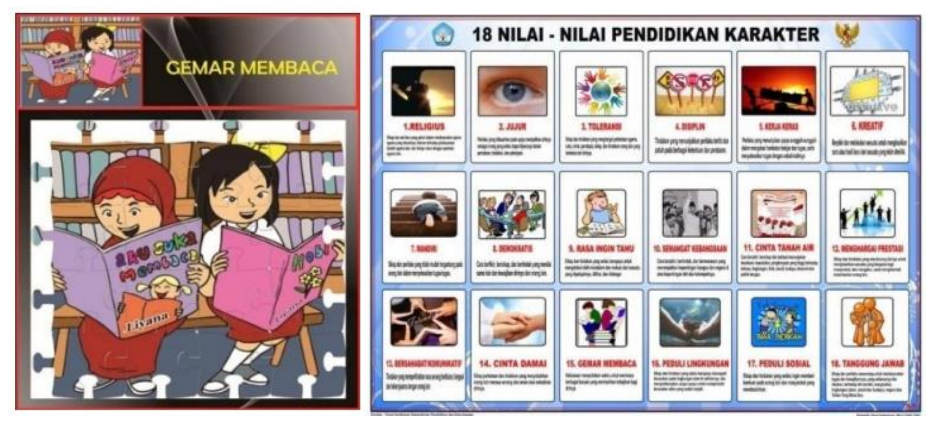

Gambar 1.2. Media Edukasi Lego (Puzzle bingo)

Pada tahun 2018, Ariyana, dkk melakukan penelitian terkait pengembangan puzzle game wayang punakawan sebagai media dalam memperkenalkan seni budaya pada anak-anak. Game ini memiliki segmentasi anak-anak dengan rentang usia 5-9 tahun karena pada rentang usia ini anak mudah terpengaruh atas apa media yang dikonsumsinya sehingga harapannya anak akan mudah mengingat budaya jawa dan tokoh punakawan di dalamnya setelah menyelesaikan permainan ini (Ariyana, dkk, 2020).

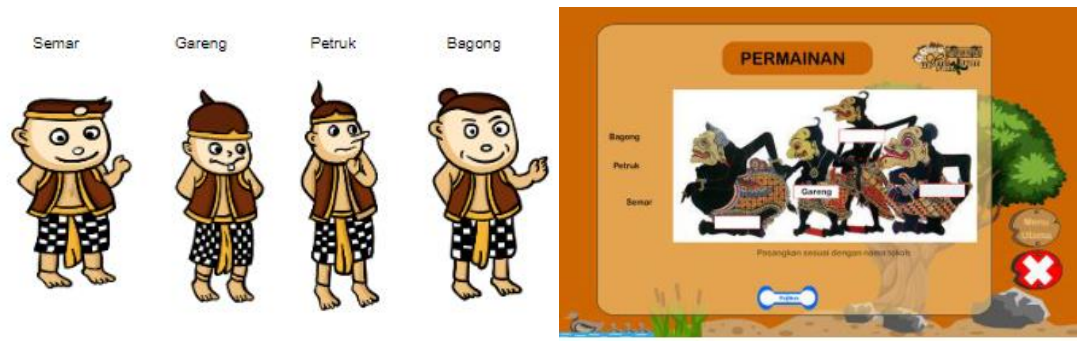

Gambar 1.3. Media Edukasi Game Puzzle Wayang Punakawan

Pada tahun 2020, Darmayasa dkk. melakukan penelitian terkait perancangan media edukasi puzzle dengan nama Edufunzle atau Education Funny Puzzle. Puzzle ini dibuat dengan tiga tahapan, yaitu menganalisis komponen fisik dasar produk, perhitungan aspek estetika dan ergonomik untuk mengoptimalkan fungsinya, dan penyempurnaan desain produk sehingga sesuai dengan segmentasi media edukasi yang dituju. Kekuatan utama dari Edufunzle ini adalah melatih motorik, kognitif, dan sensori anak dengan memperkenalkan konsep utama warna dan bentuk (Darmayasa, dkk, 2020). 


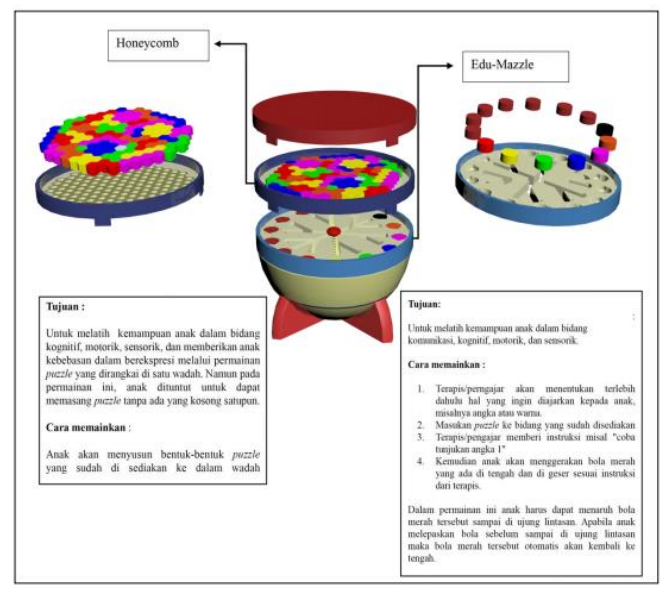

Gambar 1.4. Media Edukasi Puzzle Edufunzle

Pada tahun 2021, Adiyoga dan Purba melakukan penelitian mengenai puzzle kayu dengan tema "Puzzle 7 Hewan Langka" yang menggabungkan unsur tradisional dan modern di dalamnya. Target pengguna permainan puzzle ini adalah anak-anak usia 3-6 tahun. Bentuk dari permainan ini adalah Chibi Style, dengan dominasi warna orange dan hijau yang menggambarkan kehangatan serta suasana alam yang merupakan habitat hewan-hewan tersebut. Berikut ini adalah visualisasi dari media puzzle hewan langka (Adiyoga \& Purba, 2021).

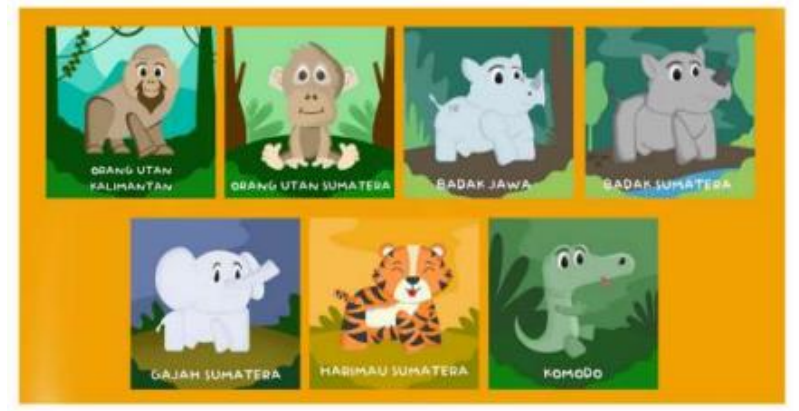

Gambar 1.5. Media Edukasi Puzzle 7 hewan langka

Hasil tinjuan pustaka menunjukkan bahwa media puzzle yang telah dibuat sebatas memperkenalkan objek yang ada di lingkungan sekitar anak. Apabila dikaji dari sisi kemampuan anak dan media edukasi puzzle yang sudah ada sebelumnya, media yang ada sudah tepat sesuai dengan tumbuh kembang anak karena memperkenalkan objek yang berada di sekitar anak. Beberapa objek yang diperkenalkan di antaranya adalah hewan, tokoh kartun, tokoh budaya, bentuk benda dan karakter positif. Media yang ada juga muncul dalam bentuk konvensional (bentuk nyata) dan digital sehingga dapat disimpulkan bahwa dengan tingkat kesulitan yang dimiliki sesuai dengan usia anak. Hal ini erat kaitannya dengan kemampuan anak di rentang usia 2-7 tahun yang masih berada pada fase pra-operasional menurut teori Piaget.

Ragam media edukasi yang telah dibuat oleh peneliti sebelumnya menunjukkan bahwa belum ada media edukasi anak yang dapat dimainkan anak secara fisik berupa puzzle yang konteks dan konten utamanya adalah perpaduan pendidikan karakter anak dengan pengembangan self-esteem dan self-confidence di dalamnya.

Di dalam diri seseorang terdapat self-esteem (harga diri), self-confidence (kepercayaan diri), dan kesadaran diri yang realistis. Penelitian yang dilakukan oleh Pratiwi dan Yanuarsari (2021) menunjukan bahwa ketika anak dapat menunjukan identitas dirinya dengan mengedepankan self-esteem dan self-confidence maka anak 
akan lebih kuat dalam melindungi dirinya dari tindakan tidak menyenangkan dari orang lain. Temuan penelitian ini menunjukan bahwa pada media edukasi yang telah ada belum ada satu media edukasi pun yang menghadirkan orang tua sebagai bagian dari figur otoritas percontohan pada anak di dalam konten media edukasi. Berdasarkan observasi peneliti di lapangan, orang tua selama ini berperan dalam penyampaian informasi untuk mempermudah anak bermain dan sebagai teman bermain anak pada media edukasi yang ada. Hal ini menjadi dasar peneliti untuk mengembangkan media edukasi yang melibatkan orang tua tidak hanya dalam proses bermain, tetapi juga memperkuat perannya dengan figur tokoh yang muncul di media edukasi secara langsung, yang berbasis pada pendidikan karakter anak dengan fokus pada self-esteem dan self-confidence anak.

Media edukasi dapat menjadi alternatif dalam penyampaian suatu pesan pada anak. Hal ini seperti yang diungkapkan oleh narasumber Maria Wening S. Handayani, berikut ini:

“...Penting banget media edukasi buat anak-anak karena sangat membantu anak dalam memahami konsep yang abstrak. Nah yang dilihat bukan hanya proses anak bermainnya, tetapi interaksi yang terjadi antara orang tua dengan anak. Namanya anak kan memang fasenya di dunia permainan , jadi ya pesanya pasti akan lebih mudah sampai kalau dengan media edukasi tadi. Sambil anak bermain, anak juga berinteraksi dengan nilai-nilai yang diajarkan orang tuanya..."

Selaras dengan Wening, Watiek Ideo selaku praktisi media edukasi anak juga menyatakan bahwa:

“...penting banget media edukasi anak, karena dunianya anak-anak kan dunia bermain ya.. jadi kalau mau menyampaikan pesan tertentu akan lebih mudah kalau pakai alat peraga dengan berbagai bentuk, yang penting mengedukasi..."

Pernyataan narasumber selaras dengan hasil penelitian terdahulu yang menyatakan bahwa media edukasi terutama berdampak positif pada kemampuan anak., baik dari sisi kognisi, motorik, hingga verbal. Dwi Permata (2020) menyatakan bahwa terjadi peningkatan ketrampilan kognitif pada anak serta peningkatan ketrampilan belajar setelah anak bermain puzzle. Anak pada rentang usia 4-5 tahun memiliki kemampuan pemecahan masalah yang semakin baik setelah anak berhasil menyelesaikan puzzle. Hal ini dikarenakan adanya kerja sama antara tangan dengan mata anak yang sedang bermain sehingga anak melakukan proses pemahaman berdasar kemampuan personalnya. Minasari dkk. (2021) melakukan penelitian mengenai pendidikan multikultural pada anak usia dini melalui permainan puzzle, di mana hasil menunjukan bahwa anak lebih mudah dalam mengingat dan mengucapkan nama-nama negara sehingga dapat disimpulkan bahwa kemampuan kognitif setelah anak bermain puzzle meningkat.

Permainan menggunakan media puzzle berpengaruh pada perkembangan kognitif anak karena dalam prosesnya anak belajar berfikir dengan melihat langsung, melakukan pengamatan berulang, dan memecahkan persoalan secara sederhana. Dalam proses menyelesaikan puzzle, anak berpikir tentang warna, jumlah, nama, dan ukuran dari suatu konsep yang ditawarkan media edukasi tersebut (Sari, dkk, 2014). Kemampuan motorik halus anak juga akan terus berkembang saat anak berhasil untuk menyelesaikan permainan puzzle. Adapun beberapa motorik halus yang berkembang diantaranya keterampilan menyusun benda, kemampuan koordinasi mata dengan 
tangan, peningkatan fokus diri pada anak, serta pengelolaan emosi karena anak memerlukan konsentrasi tinggi dalam penyelesaian puzzle (Syisva Nurwita, 2019).

Penggunaan media edukasi pada anak juga mengajarkan pada anak untuk mengendalikan diri saat menghadapi persoalan. Hal ini merupakan komponen penting dari sisi pengelolaan emosi anak. Menurut Aomodt, pengendalian diri pada anak usia dini merupakan elemen keberhasilan anak yang mendukung perkembangan anak pada tahun berikutnya. Permainan yang diajarkan pada anak menjadi media yang berkontribusi pada perkembangan fungsi otak paling dasar, yaitu pengendalian perilaku untuk tujuan tertentu. Hasil penelitian menunjukan bahwa kemampuan anak usia dini dalam mengontrol perilakunya sendiri sangat berpengaruh pada kesuksesan anak saat mengatasi persoalan konsentrasi dan pengelolaan stres di masa remajanya. Kemampuan anak dalam pengelolaan perilakunya juga berpengaruh pada kemampuan interpersonalnya yang ditunjukan dengan rasa empati yang tinggi, pengelolaan emosi serta kepekaan social (Aamodt, 2013).

Dalam perancangan media edukasi, segmentasi merupakan hal yang sangat penting. Hal ini karena setiap anak memiliki fase perkembangan dan kemampuan memahami pada setiap rentang usianya. Hal ini sesuai dengan teori perkembangan anak yang disampaikan oleh Piaget mengenai perkembangan kognitif anak. Perkembangan awal anak diawali dengan kemampuannya yang terus meningkat dalam hal sensomotorik yang kemudian berkembang menjadi pra-operasional pada rentang usia selanjutnya (2-7 tahun).

Menurut Watiek Ideo, dalam memberikan media edukasi anak perlu untuk melihat kebutuhannya.

“...anak-anak memerlukan media edukasi dengan menyesuaikan level umurnya. Ya.. karena anak kan ada fase perkembanganya ya.. Setiap anak juga memiliki kemampuan literasi informasi yang beragam. Bisa dilihat dulu juga latar belakang budayanya seperti apa. Jadi ya menurut saya, segmentasi media edukasi sendiri juga beragam dan harus jelas..."

Pernyataan WatiekIdeo selaras dengan apa yang disampaikan oleh Wening.

"Dalam membuat media edukasi anak perlu disesuaikan dengan rentang usia anak. Kalau tujuannya adalah untuk anak usia 4-5 tahun kan mereka memang berada pada fase pra operasional. Anak pada rentang usia ini belum melihat objek secara kongkrit, belum faham makna secara utuh karena masih dalam punya dunia imajinasinya sendiri..."

Tidak hanya berbicara tentang segmentasi yang spesifik, tetapi juga diperlukan pemahaman mendasar tentang kemudahan dalam memainkan media edukasi pada anak. Hal ini disampaikan oleh Watiek Ideo berikut ini:

“...Kalau bicara tentang media edukasi anak ya harusnya dalam proses perancangannya hal utama yang diperhatikan adalah sifat media itu sendiri. Kalau tujuannya memang untuk anak-anak ya konsepnya berdasar pada media ramah anak ya. Media yang sesuai dengan usia anak, simple, mudah diaplikasikan dan tidak terlalu banyak tahapan atau langkah. Karena anak-anak akan tertarik untuk bermain karena mudah ya untuk digunakan..." 
Selain media yang ramah anak, komponen lain yang juga perlu diperhatikan adalah persoalan menyederhanakan sebuah konsep sehingga dapat diterima baik oleh anak. Berikut pernyataan Maria Wening S.Handayani:

“...Kalau misal mau menceritakan ke anak tentang konsep yang absurd ya kita harus memberikan contoh kongkritnya seperti apa. Jelas batasanya seperti apa, bentuk nyatanya seperti apa. Jadi anak tidak hanya sebatas mengerti kata tapi juga paham maknanya.. Ya kalau mau mengajarkan karakter baik ya harus dioperasionalkan dengan bahasa anak-anak ya.."

Menurut Saputro dkk. (2016), penyajian informasi dapat disampaikan dalam bentuk verbal dan visual yang secara langsung melibatkan kemampuan indera penglihatan sebesar $83 \%$ dan didukung indra lainnya sehingga informasi yang disampaikan dapat diterima secara lebih optimal (Saputro, dkk, 2016).

\section{Peranan Ayah Ibu dalam Pendidikan Karakter Anak Usia Dini melalui Media Edukasi}

Pendidikan karakter merupakan upaya yang dilakukan dengan tujuan menginformasikan, mengarahkan dan menjaga agar seseorang berperilaku sesuai dengan nilai karakter yang baik. Dalam proses pendidikan karakter diperlukan pengulangan yang sifatnya berkelanjutan. Idealnya, masa pengenalan pendidikan karakter adalah pada usia dini karena nilai karakter yang tertanam pada anak akan menjadi penentu sifat maupun karakternya di masa dewasa kelak (Hadisi, 2015). Hal ini selaras dengan pernyataan Maria Wening S.Handayani.

“...4-5 tahun itu sebenernya kan proses anak mengimitasi dari anak melihat. Maka kalau mengajarkan pendidikan karakter yang konsepnya adalah mengajarkan kepatuhan yang prosesnya harus berulang. Memang sebaiknya diajarkan pada anak sejak dini. Karena pada rentang usia 4-5 kan anak belum bisa terbentuk karakter dengan sendirinya. Maka memang tepat untuk mengajarkan anak tentang konsekuensi. Sehingga nantinya karakter akan terbentuk..."

Hasil penelitian menunjukan bahwa anak lahir dengan ribuan milyar sel di otaknya sehingga sel ini menjadi aset utama anak yang harus terus diasah secara maksimal agar anak mencapai tumbuh kembang optimal sesuai dengan fase usianya. Anak usia dini memiliki spontanitas yang tinggi dalam berperilaku dan berinteraksi sehingga diperlukan arahan yang baik dari lingkungan sekitarnya, yaitu orang tua. Pendidikan karakter menjadi jawaban atas kebutuhan tumbuh kembang anak karena anak belum memahami konteks berperilaku yang baik sesuai dengan norma yang berlaku di masyarakat (Khaironi, 2017).

Pendidikan karakter bagi anak usia dini adalah bagaimana menanamkan kebiasaan mengenai perilaku yang baik dalam kehidupan sehingga dengan pendidikan karakter yang diterima anak mampu menyadarkan anak tentang komitmen atas perilaku dirinya dalam proses berinteraksi di masyarakat. Ketika seorang anak ditanamkan pendidikan karakter maka akan menjadi kebiasaan sikap dirinya hingga dewasa sehingga diperlukan proses pengulangan yang didukung oleh berbagai pihak, terutama di lingkungan keluarga (Cahyaningrum, dkk, 2017). 
Menurut Maria Wening S.Handayani, hal terpenting dalam mengajarkan pendidikan karakter pada anak adalah dengan menggunakan bahasa yang jelas terukur sesuai dengan pemahaman anak.

“...Kalau kita sebagai orang dewasa mau memperkenalkan konsep karakter pada anak misalnya Bohong dan Jujur ya kita harus bisa mengoperasionalkannya dalam bahasa anak. Batasanya sampai dimana? Apa yang boleh dan tidak boleh dia lakukan. Maka sebagai orang dewasa, atau orang tuanya ya harus bisa mendeliver pesan itu dengan baik. Ya yang penting sih value utamanya apa..."

Dalam mendidik anak, orang tua tidak hanya berperan sebagai pengarah dan penanam nilai karakter pada anak, tetapi orang tua juga harus siap secara psikologis dalam memberikan percontohan pada anak. Hal ini tegas disampaikan oleh Maria Wening S.Handayani sebagai berikut:

“...Orangtua harus siap mental sepenuhnya saat mau mengajarkan pendidikan karakter ke anak. Jangan sampai hanya sebatas omongan aja, tapi gak dikasih contoh. Misalnya: kita mengajarkan jangan berbohong sementara kita bohong ke anak. Nah, ini kan berarti mental kita yang gak siap. Kemudian kita harus mempersiapkan value utama yg mau diajarkan ke anak itu apa dan konsisten mencontohkannya dalam bentuk sikap kita.."

Anak usia dini secara alamiah memiliki sifat meniru. Apa yang dilihat oleh orang-orang di sekitar anak akan menjadi percontohan bagi dirinya dalam berperilaku. Orang-orang dewasa yang berada di lingkungan terdekat anak perlu menjadi figur contoh yang baik bagi anak karena merekalah yang akan menjadi komunikator dalam pendidikan karakter anak usia dini pada tahap awal (Cahyaningrum, 2017).

Penyampaian informasi atau pesan terkait pendidikan karakter anak merupakan hal yang menarik untuk didiskusikan. Anak yang besar dalam lingkungan pertama di keluarga tentu saja memiliki orang tua yang menjadi dunia percontohan dan kepatuhannya pertama kali. Dalam hal pendidikan anak, baik ayah maupun ibu, memiliki peranan masing-masing dalam penyampaian pesan pendidikan karakter anak, seperti pernyataan Maria Wening S.Handayani berikut ini:

“...Kalau bahas soal pendidikan sebenernya kan bisa siapa saja yang menyampaikan ya.. kalau peran ayah sebenarnya kan sebagai figur otoritas yang menunjukan bagaimana si mengambil keputusan, pengelolaan emosi saat muncul masalah, dan sosok maskulin yang ditaati. Kalau ibu kan figure pusat emosi sehingga ibu akan ditampilkan sebagai sosok yang menyenangkan dan menenangkan. Nah kalau bahas soal kemandirian maka yang akan muncul adalah figur ayahnya, kalau pelindung atau yang menenangkan ya ibunya..."

Keluarga merupakan faktor penting sekaligus penentu atas keberhasilan pendidikan karakter seseorang. Hal ini karena hingga anak berusia 18 tahun lebih dari 60\% waktunya dihabiskan bersama dengan keluarga. Orangtua akan menjadi figur utama yang diperlukan anak dalam mengelola sikapnya hingga dewasa. Karakter anak akan terbentuk optimal sejak anak berusia tiga tahun sehingga hal ini dapat menjadi indikator tumbuh kembang anak dari sisi responnya pada lingkungan atau kecerdasan emosional anak (Pratiwi, 2018). 
Peranan orang tua dalam media edukasi yang selama ini dilakukan adalah orang tua berperan sebagai penyampai pesannya. Orangtua yang membaca aturan permainannya, bermain bersama anak, atau mengarahkan teknis cara bermainnya dalam proses bermain dengan media edukasi. Menurut Watiek, yang terpenting adalah proses interaksi orang tua anak sehingga anak akan terbiasa nyaman dengan orang tuanya. Hal ini akan menjadi bekal anak dalam perkembangannya dengan teman sebaya.

Orangtua sangat berperan dalam proses penentuan tujuan yang ingin dicapai keluarga termasuk pengelolaan sikap yang diajarkan melalui pendidikan di lingkungan keluarga (Hapsari dkk, 2020). Watiek menyatakan bahwa peranan keluarga sangat penting dalam penguatan konsep diri anak.

“...Penguatan konsep diri dlm keluarga penting bgt untuk membangun karakter anak sejak dini. Karena lingkungan terdekat bagi anak kan keluarga ya. Kalau konsep diri anaknya kuat ya dia akan tumbuh jadi pribadi yang terbuka dan akan sangat percaya terhadap keluarganya..."

Konsep diri sangat berpengaruh dalam perkembangan aktualisasi diri seseorang. Komponen yang berasal dari dimensi internal merupakan sudut pandang diri berdasar pada diri sendiri yang memiliki tiga bentuk utama, yaitu self-identity, behavioral self dan judging self. Identitas diri merupakan bagian utama pada konsep diri yang mempertanyakan tentang diri dan pada akhirnya menjadi rangkaian dasar interaksi dengan lingkungan. Behavioral self menjadi dasar perilaku berdasar pada persepsi diri dan merupakan bentuk nyata identitas diri yang terbentuk. Judging self (diri penerima) merupakan standarisasi diri atas dirinya berdasar pada penerimaan diri (Pratiwi \& Yanuarsari, 2021).

\section{Kesimpulan}

Penelitian ini memiliki lima objek penelitian yaitu lima media edukasi yang telah dikembangkan oleh peneliti sebelumnya. Hasil analisa peneliti dengan berbasis pada studi literatur dan hasil wawancara menunjukan bahwa media edukasi yang telah ada belum ada satupun yang berbasis pada peranan orang tua dan pendidikan karakter anak. Jika ditelaah lebih lanjut, orang tua memiliki peran utama sebagai keberhasilan penyampai pendidikan karakter pada anak. Ketika seorang anak berhasil untuk melampaui fase pendidikan karakter dengan baik maka secara langsung konsep diri anak akan lebih kuat terbangun terutama dari sisi dimensi internal, yaitu self-identity, behavioral self, dan judging self. Hasil penelitian menunjukan bahwa media edukasi puzzle dapat menjadi solusi penyampai pendidikan karakter pada anak dan diperlukan rancangan media edukasi berupa puzzle berbasis pada pendidikan karakter serta peranan orang tua dengan tujuan pengembangan self-esteem dan self-confidence didalamnya.

\section{Referensi}

Aamodt, S. (2013). Cara Pikiran Berkembang dari Masa Pembuahan hingga Kuliah: Welcome to Yur Child's Brain. Jakarta: PT. Gramedia Pustaka Utama.

Abdullah, M. Y., Hastuti, W., \& Karmila, A. (2016). Lego ( Puzzle Bingo ) Games : Media Edukatif Berbasis Pendidikan Karakter Pada Anak Usia Sekolah Dasar Dalam Mewujudkan Generasi Indonesia Emas. Jurnal PENA, 2, 296-307.

Adiyoga, D., \& Purba, R. (2021). PERANCANGAN PERMAINAN PUZZLE KAYU SEBAGAI MEDIA PEMBELAJARAN DAN. 141-152. 
Admin, P. (n.d.). Memahami Pendidikan Anak Usia Dini. Retrieved from 2016 website: http://paud.kemdikbud.go.id/2016/03/30/memahami-pendidikan-anak-usiadini/

Akhyadi, A. S., \& Mulyono, D. (2019). Program Parenting Dalam Meningkatkan Kualitas Pendidikan Keluarga. Abdimas Siliwangi, 1(1), 1. https://doi.org/10.22460/as.v1i1p1-8.34

Cahyaningrum, E. S., Sudaryanti, S., \& Purwanto, N. A. (2017). Pengembangan Nilai-Nilai Karakter Anak Usia Dini Melalui Pembiasaan Dan Keteladanan. Jurnal Pendidikan Anak, 6(2), 203-213. https://doi.org/10.21831/jpa.v6i2.17707

Darmayasa, P. P., Hartono, M., \& Ronyastra, I. M. (2020). Perancangan Mainan Puzzle untuk Media Belajar dan Media Terapi Motorik Halus bagi Anak Autis. KELUWIH: Jurnal Sains Dan Teknologi, 1(2), 69-76. https://doi.org/10.24123/saintek.v1i2.2978

Dewi, T. U., \& Handayani, S. L. (2019). Penanaman Nilai Karakter Melalui Permainan Outdoor Bagi Anak-Anak Usia Dini di Wilayah RW 01 Kelurahan Pekayon Kecamatan Pasar Rebo Jakarta Timur. Publikasi Pendidikan, 9(1), 1. https://doi.org/10.26858/publikan.v9i1.6418

Dwi Permata, R. (2020). Pengaruh Permainan Puzzle Terhadap Kemampuan Pemecahan Masalah Anak Usia 4-5 Tahun. PINUS: Jurnal Penelitian Inovasi Pembelajaran, 5(2), 1-10. https://doi.org/10.29407/pn.v5i2.14230

El-Khuluqo, I. (2015). Manajemen PAUD (Pendidikan Anak Usia Dini): Pendidikan Taman Kehidupan Anak. Yogyakarta: PT. Pustaka Pelaja.

Farasonalia, R. (2021). Selama Pandemi Covid-19, Kasus Anak Berhadapan dengan Hukum di Jateng Meningkat 10 Persen. Retrieved May 17, 2021, from https://regional.kompas.com/read/2021/01/04/22393921/selama-pandemicovid-19-kasus-anak-berhadapan-dengan-hukum-di-jateng?page=all

Hadi, A. (n.d.). Nilai-nilai Pendidikan Keluarga dalam UU No.23 Tahun 2002 Tentang Perlindungan Anak. An-Nisa, 9(2), 101-121.

Hadisi, L. (2015). Pendidikan Karakter Pada Anak Usia Dini La Hadisi. Jurnal Al-Ta'did, 8(2), 50-69. Retrieved from http://repository.iiq.ac.id/handle/123456789/228

Hapsari, S. A., Pratiwi, M. R., \& Indrayani, H. (2020). Konten Edukasi Pengasuhan Anak Melalui Media Online Komunitas Parenting Keluargakita.Com. In International Conference Communication and Sosial Sciences (ICCOMSOS), 1(1).

Hasanah, U. (2016). Pengembangan Kemampuan Fisik Motorik Melalui Permainan Tradisional Bagi Anak Usia Dini. Jurnal Pendidikan Anak, 5(1), 717-733. https://doi.org/10.21831/jpa.v5i1.12368

Ikhsanudin, A. (2018). Ada 504 Kasus Anak Jadi Pelaku Pidana. KPAI Soroti Pengawasan Ortu. Retrieved from https://news.detik.com/berita/d-4128703/ada-504-kasusanak-jadi-pelaku-pidana-kpai-soroti-pengawasan-ortu

Khadijah. (2015). Media Pembelajaran PAUD. Medan: Perdana Publishing.

Khaironi, M. (2017). PENDIDIKAN KARAKTER ANAK USIA DINI. Golden Age Universitas Hamzanwadi, 01(2), 82-89.

Khoiri, Q. (2018). Dimensions Of Islamic Education In The Prevention Bullying; Assessing In an Effort of Character Building for Children In School. Publikasi Pendidikan, 8(2). https://doi.org/10.26858/publikan.v8i2.5560

Marilena, T. (2015). The Role of Parents in Integrating their Own Children in Society. Procedia - Social and Behavioral Sciences, 180(November 2014), 1680-1685. https://doi.org/10.1016/j.sbspro.2015.05.067

Minasari, A., Indraswati, D., Purwasito, A., \& Setiawan, I. A. (2021). Perkenalan Dunia 
Internasional sebagai Pendidikan Multikutural pada Anak Usia Dini melalui Metode Bermain Puzzle. Jurnal Obsesi : Jurnal Pendidikan Anak Usia Dini, 5(2), 2124-2133. https://doi.org/10.31004/obsesi.v5i2.733

Mu'min, S. A. (2013). Teori Pengembangan Kognitif Jian Piaget. Jurnal AL-Ta'dib, 6(1), 89-99. Retrieved from https://ejournal.iainkendari.ac.id

Pratiwi, M. R., \& Yanuarsari, D. H. (2021). Konten Media Edukasi Anak Berbasis Self Concept Theory. EKSPRESI DAN PERSEPSI: Jurnal Ilmu Komunikasi, 4(2), 75-86.

Pratiwi, M. R., Yusriana, A., \& ... (2019). IDENTITAS VIRTUAL DALAM INSTITUSI PENDIDIKAN MELALUI AKUN@ udinus_smg. ... On Communication and .... Retrieved from https://proceeding.umn.ac.id/index.php/COMNEWS/article/view/1100

Pratiwi, N. K. S. (2018). PENTINGNYA PERAN ORANG TUA DALAM PENDIDIKAN KARAKTER ANAK USIA SEKOLAH DASAR. (April), 83-91.

Prihatsanti, U., Suryanto, S., \& Hendriani, W. (2018). Menggunakan Studi Kasus sebagai Metode Ilmiah dalam Psikologi. Buletin Psikologi, 26(2), 126. https://doi.org/10.22146/buletinpsikologi.38895

Rahardjo, M. (2017). STUDI KASUS DALAM PENELITIAN KUALITATIF: KONSEP DAN PROSEDURNYA. Manajemen Asuhan Kebidanan Pada Bayi Dengan Caput Succedaneum Di Rsud Syekh Yusuf Gowa Tahun, 4, 9-15.

Rahmasari, E. A., Yanuarsari, D. H. (2017). Kajian Usability Dalam Konsep Dasar User Experience Pada Game Kids-Tracing And Phonics Sebagai Media Edukasi Universal Untuk Anak. Demandia. Demandia: Jurnal Desain Komunikasi Visual, Manajemen Desain, Dan Periklanan, 49-71.

Retno Dwiyanti. (2013). Peran Orang Tua Dalam Perkembangan Moral Anak (Kajian Teori Kohlberg). Prosiding Seminar Nasional Parenting, 161-169.

Rofiah, S. (2021). Pendahuluan Alat peraga Edukasi Indoor adalah alat peraga yang memiliki fungsi ganda sebagai media permainan dan juga sebagai media pembelajaran anak. Media ini bisa digunakan di dalam ruangan dan diperuntukkan untuk anak usia dini sampai usia sekolah da. 04(01), 1-14.

Saputro, G. E., Haryadi, T., \& Yanuarsari, D. H. (2016). Perancangan Purwarupa Komik Interaktif Safety Riding Berkonsep Digital Storytelling. ANDHARUPA: Jurnal Desain Komunikasi Visual \& Multimedia, 2(02), 195-206. https://doi.org/10.33633/andharupa.v2i02.1207

Sari, Y. R., Jaya, M. T. B. ., \& Anggraini, G. F. (2014). PENGGUNAAN MEDIA PUZZLE TERHADAP PENINGKATAN KEMAMPUAN PEMECAHAN MASALAH ANAK USIA 5-6 TAHUN. 42(9), 6-10.

Suhendi, A. (2010). 62,7 Persen Remaja SMP Tidak Perawan. Retrieved September 13, 2021, from https://sains.kompas.com/read/2010/06/13/08364170/ Megapolitan News Syisva Nurwita. (2019). Pemanfaatan Media Puzzle dalam Mengembangkan Motorik Halus Anak di PAUD Aiza Kabupaten Kepahiang. Journal of Chemical Information and Modeling, 3(4), 804.

Wardhani, G. W., \& Warjiyono. (2014). Perancangan Animasi Interaktif Berbentuk Puzzle Guna Melatih Kecerdasan Visual Spasial Anak. II(1), 52-59.

Yanwastika Ariyana, R., Kumalasanti, R. A., \& Mansyur, M. (2020). Pengembangan Puzzle Game Wayang Punakawan Sebagai Media Pengenalan Seni Dan Budaya Pada Anak. Jurnal Teknologi, 13(1), 53-62.

Zahro, I. F. (2015). Penilaian dalam Pembelajaran Anak Usia Dini. Tunas Siliwangi, 1(1), 92-111. 